\title{
Documentation of Palu'e Storytelling and folklore
}

\author{
STEFAN DANEREK
}

\begin{abstract}
This paper presents Palu'e storytelling on the basis of the on-going work with the Palu'e audio collection, created in the context of language/oral traditions documentation. The main aim is to show that the collection is a research resource for the humanities by discussing and comparing items which are referenced and accessible in the Kaipuleohone Ethnographic Archive. While the contents of the collection are showcased for this specific presentation, the intention is directed towards the body of digital humanities collections. The problems of what genres should be included, definitions, method of analysis, are discussed and put to the test. Recordings initially focused on oral literature, but expanded to include personal narratives with content related to culture and tradition. The cross-referencing between genres and items demonstrates the benefits of a comparative methodology, and suggests ways of using the collection.
\end{abstract}

KEYWORDS

Storytelling; language documentation; oral traditions; folklore; digital humanities; Palu'e.

\section{INTRODUCTION $^{1}$}

This paper presents Palu'e oral traditions, particularly storytelling, on the basis of the on-going work with the Palu'e audio collection (Danerek 2016-), created in a language and oral traditions documentation project and stored

1 Acknowledgements: The research was carried out from 1 November 2013 to 31 October 2016 under the auspices of the Ministry of Research, Technology, and Higher Education of the Republic of Indonesia (RISTEKDIKTI). I am very grateful to the Association for Oral traditions (ATL), and its chairperson Dr Pudentia Maria Purenti Sri Sunarti, for being my partner organization. I am equally grateful to my Palu'e assistants: Hilarius Ratu, Maria Methi (Puine), and Pidhu Sophune (see Appendix).

STEFAN DANEREK was awarded a PhD in Indonesian from Lund University, Sweden, in 2007. He is still doing work on the Palu'e language, and the audio collection and documentation of Palu'e tenun ikat for revitalization [www.instagram.com/paluetextiles]. Stefan also translates modern Indonesian literature into Swedish, most recently Eka Kurniawan's debut novel Cantik itu luka for Nilssons Förlag (2017). Stefan Danerek may be contacted at: Cawalunda@yahoo.se.

(C) 2017 Faculty of Humanities, Universitas Indonesia

STEFAN DANAREK | DOI: 10.17510/wacana.v18i3.634. 
at Kaipuleohone, the digital language archive of the University of Hawai' $i .^{2}$ The aim is twofold: to demonstrate the collection as a research resource for the humanities, and to draw attention to the growing body of intangible heritage collections in digital archives around the world - more or less accessible and adequately described - and awaiting users. To be of use to researchers is one of the major motivations behind the digital collection initiatives but, as far as I know, it is still unusual for scholarly publications to use detailed references to materials in archived collections. This paper refers to individual items which are accessible at Kaipuleohone and, while showcasing the contents, points out how the Palu'e audio collection, and similar collections, can be used. ${ }^{3}$

The documentation was carried out between late 2013 and late 2016, with several rounds of fieldwork, totalling about ten months, by one primary investigator, aided from March 2014 by one principal Palu'e assistant who was involved in every part of the project. Initially recordings focused on conventional oral literature and oral history, but gradually expanded to include anything of cultural or ethnographic value. The goal has been to create a comprehensive and polyphonic cultural repository with voices from all of the islands' fourteen traditional domains, dhana (tribal land with borders) and mutually intelligible dialects. ${ }^{4}$

That idea ties in well with the Palu' e conception of custom, adha (Ind. adat), ${ }^{5}$ which is the sum of all inherited knowledge. The majority of the recordings are prose narratives told by one narrator, and often contain a minimum of dialogue or interview between the source and the recorder (investigator or assistant). ${ }^{6}$

\section{About the PALu'e}

Palu'e is a small island of $72 \mathrm{~km} 2$ with an active volcano, located about $15 \mathrm{~km}$ off the north coast of Flores in the Eastern Indonesian province Nusa Tenggara Timur (NTT) (see Picture 1). Palu'e also denotes the island's native inhabitants, ata $\mathrm{Lu}^{\prime} a$, in their common language Sara $L u^{\prime} a$ (ISO 639-3 code ple), ${ }^{7}$ which is

\footnotetext{
2 Until recently it was called the Kaipuleohone Ethnographic Archive. Language documentation strives "to provide a comprehensive record of the linguistic practices characteristic of a given speech community" (Himmelmann 1998: 166). Documentary linuistics; language documentation, "is concerned with the methods, tools, and theoretical underpinnings for compiling a representative and lasting multipurpose record of a natural language [...]" (Gippert, Himmelmann, and Mosel 2006: v). See a summary of the field's characteristics in Himmelmann (2006: 15).

3 Items consist of a wav-file, an EAF-file with transcription, Indonesian translation and metadata in English, and often a jpeg-file, usually a portrait. The EAF annotation files open with ELAN (2017). Items are numbered upwards consecutively from SD1-000, a pdf-file with information about the collection and the project, including the process of gathering data.

4 According to Michael Vischer (2006: 179), Palu'e is divided into fourteen separate territorial, political and ceremonial domains..

5 All Sara Lu'a words are defined in a Sara Lu'a-Indonesian dictionary created with the aid of Toolbox Dictionary Factory. The dictionary manuscript supports the annotation work and vice-versa.

6 There are more than a hundred contributors. Many of them have contributed in more than one category, often fairy-stories and a genre of local healing (ngiru huru).

7 ISO 693-3 is an international standard for language codes representing names of languages.
} 


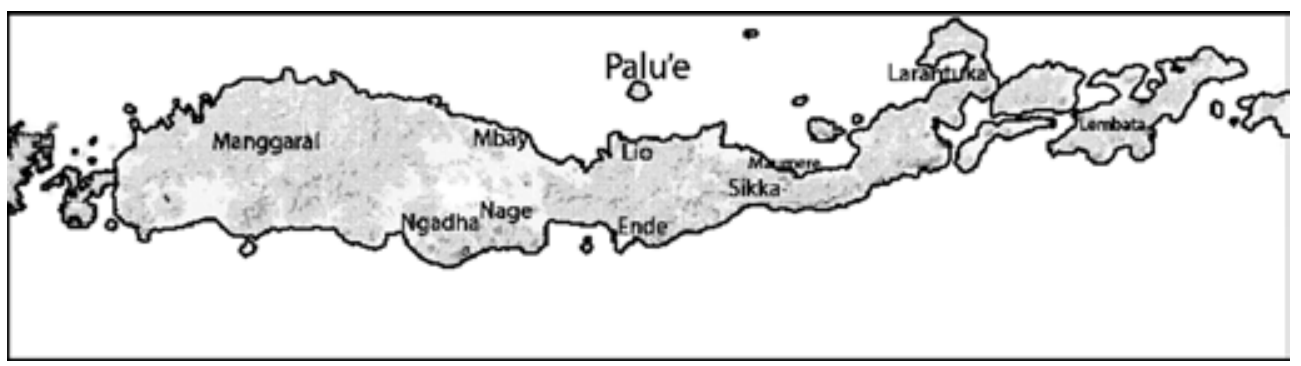

Picture 1. Map of Palu'e (image by the author, 2016).

Traditionally Palue's approximately 10,000 inhabitants are horticulturalists and fishermen. ${ }^{8}$ The island lacks fresh water. Before the arrival of water tanks which store rainwater, the people derived most of their fluid from tapping the lontar palm and other plants. Fishermen once had a tradition of leaving the island to go fishing for several months. Nowadays, most men migrate for work, often to Malaysia, and return after an absence of a few years, or even longer. People also work in the local administration, on village and municipality level, and as nurses and teachers. Women traditionally work on the family plantations more than the men, as the latter are often away, and they also weave cloths which are important in the local dowry system of goods exchange, and nowadays as an extra source of income.

A few thousand Palu'e have relocated to Flores because of the recurring volcanic eruptions of Mount Rokatenda; the latest was a string of minor eruptions which began in late 2012 and ended with the large eruption on 10 August 20139 which claimed several lives. As a consequence, the project was begun in refugee camps in Flores, in a period of limbo in which a red zone was imposed by the authorities. ${ }^{10}$

As the Palu'e are tied to their lineage houses, in which the kuku lolo (nails and hair) of the deceased are kept, someone must always stay behind. Preferably everyone should knuckle down and remain on the island until the eruptions have passed. For these reasons, the red zone curfew failed to achieve its purpose. Despite all good intentions, the threat of the active volcano and the provincial government's endeavour to relocate the Palu'e are considered threats to their culture and language. There is evidence of language shift and attrition, primarily because of the migration to Malaysia, Batam and elsewhere, not to mention the influence of the national language. Nevertheless, the larger Flores languages have not had any, significant influence on Sara Lu'a. Although Palu'e people who work on Flores learn the related Lio language with relative ease, they rarely learn the more divergent and more difficult

8 Traditional crops are tubers and mung beans. Nowadays cashews are grown as a cash crop. See Vischer (1993: 204-209) for a dense description of Palu'e society.

9 See http://www.bbc.com/news/world-asia-23646467. I experienced a small eruption and an earthquake around 1 March 2014. There were no victims.

10 I made my first trip ever to Flores and NTT in September 2013 to see if it was still possible to carry out the project, and to make contacts. 
Sikka language. Children still learn Sara Lu'a before Indonesian, and Sara Lu'a is still used on Palu'e more than Indonesian, which is why outsiders consider the language vigorous, as it is categorized in Ethnologue (Lewis, Simons, and Fennig 2017). Whatever the outside world thinks, more educated locals consider Sara Lu'a under threat of extinction. Language shift and migration are the main problems, something to which the recordings bear witness: it is unusual that a recording will be 100 percent in Sara $L u^{\prime} a$, even after the narrator has been instructed to narrate in Sara $L u^{\prime} a$ only. This is also true of senior narrators, especially in the kampongs by the coast. ${ }^{11}$ The most urgent problem occurs when specific language domains and speak-genres disappear when the knowledgeable elders pass away without having passed on their knowledge to the younger generation, a process called transmission failure. The consequence is traditional knowledge and ritual language, which was not separate from the daily language, and the corpuses of both major and lesser rituals, are threatened. The priest-leaders of a domain, lakimosa, and their families, are the main keepers of both the major and the lesser ceremonies. ${ }^{12}$

Traditional life on Palu'e remained intact well into the first decades of the twentieth century when the Dutch pacified the island and brought it under their administrative control. A Roman Catholic mission was established in the late 1920s, but Catholicism only became dominant in the 1950s. Today almost all Palu'e are Roman Catholics. As has happened elsewhere, animist beliefs, traditional ceremonies, and rituals devoted to the ancestors and the Supreme Being, Hera Wula, and Watu Dhana (Sun Moon, Stone Soil), have gradually lost prestige and sacrality after conversion.

Ancestors are still highly revered. Some parts of the adat are still strong, particularly the dowry system which binds families and alliances together in a system of reciprocal exchange and particularly in the hillside domains of buffalo blood, whose ritual systems are more elaborate than those of the coastal domains of pig blood. Traditionally, the buffalo blood domains have had a five-year period of expansion which begins with the joyous ritual Pua Karapau (Bringing the Buffalo) lasting more than a week. It is held when young buffaloes are brought to the island. ${ }^{13}$ The agricultural cycle ends with Pati Karapau (Cutting the Buffalo) five years later, when the adult buffaloes are sacrificed, which ushers in an up to five-year-long period of restrictions and

11 Generally the Sara lu'a content is over $90 \%$. I have discarded recordings/speakers in which a higher rate of Indonesian occurred because they would not be useful as a language resource. A poor command of Sara Lu'a was also consistent with a more deficient knowledge of culture. There are indigenized Malay/Indonesian loanwords. Names for newer things from outside usually remain Indonesian, but some are given local names, for instance aeroplane: pou lai (flying boat).

12 Palu'e society is also stratified through marriage alliances between lineage houses, such as those of the lakimosa families and through clans (kunu). The categories allow limited social mobility and are identified by ancestry and ritual. Kinship is patrilineal and based on membership of individual houses which represent descent.

13 There are five nights of ritual dancing $(\operatorname{tog} o)$ after the buffalo has arrived in the village. The buffalo is a water buffalo and it cannot live on the island unless it is fed a daily diet of succulent plants, because there are neither natural streams nor irrigation. 
prohibitions (bhije). The prohibitions slow down development significantly. This is the reason that concrete houses often stand uncompleted, and is exacerbated by the fact that Palu'e is relatively poor. The major ceremonies and the traditional exchange system require significant resources. Family investments are also spent on modern-day celebrations, marriages and religious confirmations. Palu'e has no guesthouses yet, nor are there any shops which are not referred to as kiosks. Since the late 1990s, motorcycles have been important for transportation. Since 2017, apart from visiting trucks, which are used in the construction of a primitive road system or other building projects, there are three pickups.

\section{ON DEFINITIONS, USE, VALUE, METHOD, CONTEXT}

According to the Oxford English Dictionary (2017), folklore is "a community's beliefs, customs and stories, passed through the generations by word of mouth". It is a condensed version of how the Indonesian university programme for studies of oral traditions (Kajian Tradisi Lisan, KTL) defines oral traditions. ${ }^{14}$ Indonesian folklorist James Danandjaja (2010b: 73) defines folklore along the same lines but, in a book compiled for KTL, he expands the scope to cover folk architecture and painting. In another chapter, he emphasizes that, in a modern holistic approach, the "folk" part of folklore should also be paid significant attention (Danandjaja 2010a: 67). Moreover, folklore is essentially, but not exclusively, oral. Folklore studies have traditionally conceptualized its raw material as collectively inherited without a single author, just as do present studies of oral traditions. Henceforth I make no distinction between oral folklore and oral traditions and, within the stated aims, elaborate on four common and interrelated matters which researchers must consider in documentation: 1) Definitions, to enable a discussion, particularly of narrative types, to distinguish and to compare. 2) What should be included in a collection? In particular, what should be done when you do not find the commonly sought genres, the ritual songs, legends, fairy-stories, myths and fables? 3) The value and use of the material which derive partly from the definitions and what should be included. 4) A comparative method of analysis is also a good indicator of value and use.

I believe that studies of oral prose genres should be comparative, diverging to some extent from studies of written literature, because they require fieldwork or an ethnographic accounts and because stories change over time and differ from narrator to narrator. The problem of fixity is more relevant to the ritual and poetic genres. Following Mikhail M. Bakhtin's (1981) thoughts on language and discourse in literature, the folk tradition is a factor which determines narrative structure and content "from within", not least in the

14 KTL and its supporting precursor, the Association for Oral Traditions (Asosiasi Tradisi Lisan, ATL), allows a wide definition of oral traditions. For instance, traditional law and medicine are included, but handicraft is not (Pudentia MPSS 2015: 16, and personal communication). An oral cultural practice is regarded as a tradition after at least two generations, or about 50 years. KTL theses must address the future and possible revitalization of the traditions studied. 
more personal non-traditional story categories. ${ }^{15}$ The benefits of and need for a comparative approach are obvious when the collection/samples have to cover a wide range

The conventional genres mentioned are oral literature and belong to those genres that folklorists have traditionally and primarily understood as folklore. Swedish-American folklorist Barbro Klein (2006: 8) tells of how folklore studies gradually grew to include new material.

[M]any genres that folklorists recognize today, were not considered "real" folklore and were not recorded and investigated. "True" or "authentic" folk narratives were thought to exist as recognizable, "traditional" types that [...] were handed down "from generation to generation" or were transmitted "from mouth to ear". Even as late as the 1960s such genres as "local histories", "personal experience narratives", and "life stories" were not generally included within the domains of folklore study.

Swedish folklorist Carl Wilhelm von Sydow proposed the influential term memorate [1934] for a folklore sub-genre of non-traditional oral prose in the form of a personal narrative based on memory. This often involved an encounter with a supernatural being (Von Sydow 1948). With the passing of time, Von Sydow's narrow definition and urge to distinguish the memorate from other sub-genres attracted criticism. The Finnish folklorist Martti Haavio ([1942] in Honko 1964: 13) examined folklore collections and came to a different conclusion to that of Von Sydow, who had stressed individual and unique elements: "Those memorates in which the individual element is dominant are noticeably rarer than those in which the motifs are connected with the general folk tradition." Finnish folklorist Lauri Honko argued that memorates are primary sources in investigating empirical evidence of supernatural beings, and that memorates can develop into legend (1964: 13-14). He demonstrated the value of memorates when investigating folk beliefs, by virtue of being closer to belief legends than fabulates, Von Sydow's term for a narrative with a solidified, replicated structure.

American folklorist Sandra Dolby-Stahl (1989: 15) developed the memorate concept to the "oral personal narrative" which stresses the conditions of a narrator-self who is present in the story and truthful about the related events, a dramatic structure and, as Bakhtin reminds us, an indirect presence of tradition expressed through the narrator's worldview. Luisa Maffi, director of Terralingua, ${ }^{16}$ expresses a current and relevant view in a special edition about oral traditions documentation and revitalization (2014: 4):

15 It is the intentional dimension of literature, its worldview, which "requires the concrete social context of discourse [...] to be revealed as the force that determines its entire stylistic structure [...] from within" (Bakhtin 1981: 300).

16 Organization devoted to linguistic and bio-cultural diversity. 
[...] oral traditions more broadly also include personal narratives and oral histories, through which people record and communicate their individual and collective past and their links with past generations and ancestors, with times, places, and events of particular significance, and with all of the intangible heritage, both cultural and natural, that makes people who they are.

During my first two months of fieldwork, more a period of learning the language and the situation, I did not record anything meaningful. I wanted to record the traditional folk genres, but I could not find any able and willing narrators. The villagers said that the last of the elders, who would have been able to tell them, had passed away a few years before my arrival.

People were often hampered by the thought that they lacked knowledge, or just knew some parts of a legend. They referred back to a golden age when the people really knew things. But, as time passed, I found that there were indeed persons who could tell about such other matters as more personal stories. Judging by Von Sydow's encounters with the memorate, this problem has plagued these studies since their inception. Under the circumstances, I decided to make the best use of the personal narratives, notably oral histories and narratives which concern tradition, for the wider purpose of assembling a culture and a language. The annotation process, which I find hermeneutical and analytical, influenced the decision even more as I saw that individual items illuminated each other. Dolby-Stahl (1989: xxxii) expresses the value of oral personal narrative:

The successful teller of personal narrative engages the listener in an adventure[...] the shared activity of exploring the teller's world, the teller's identity. [...] There is a treasure in each story [...] the experience of hearing another voice, of seeing $[\ldots]$ someone else in a subjective world.

Dolby-Stahl's evaluation brings us to a definition of folklore which considers the performance context: artistic communication in small groups (Dan Ben-Amos 1971: 10). The performance context makes us consider ourselves. In the documentation, it has primarily been either myself or an assistant who has been present as attentive listener(s), able to share in the culture of the narrator, the context which enhances analysis. ${ }^{17}$ Often, one or two of the narrator's family members or friends were also present. There were often children and or others in the vicinity, whether we were indoors or outside. Silence is unusual in a kampong. The setting has most often been inside the house or on a woga (bamboo platform) outside. The prose genres are not part of any ceremonies, which means that they can be told at any time. However, the folk-tales are not told very often, if ever. Therefore, just by recording them they have become revitalized, as people begin to think, ask around and remember. Humorous fables and some fairy-stories especially are still told by senior family members to the younger generation, in the afternoon

17 Ceremonies, such as the rituals and ritual chants during the buffalo ceremonies, have also been recorded when they were performed (by large groups). 
or evening. Various tales were recorded in such a setting. ${ }^{18}$

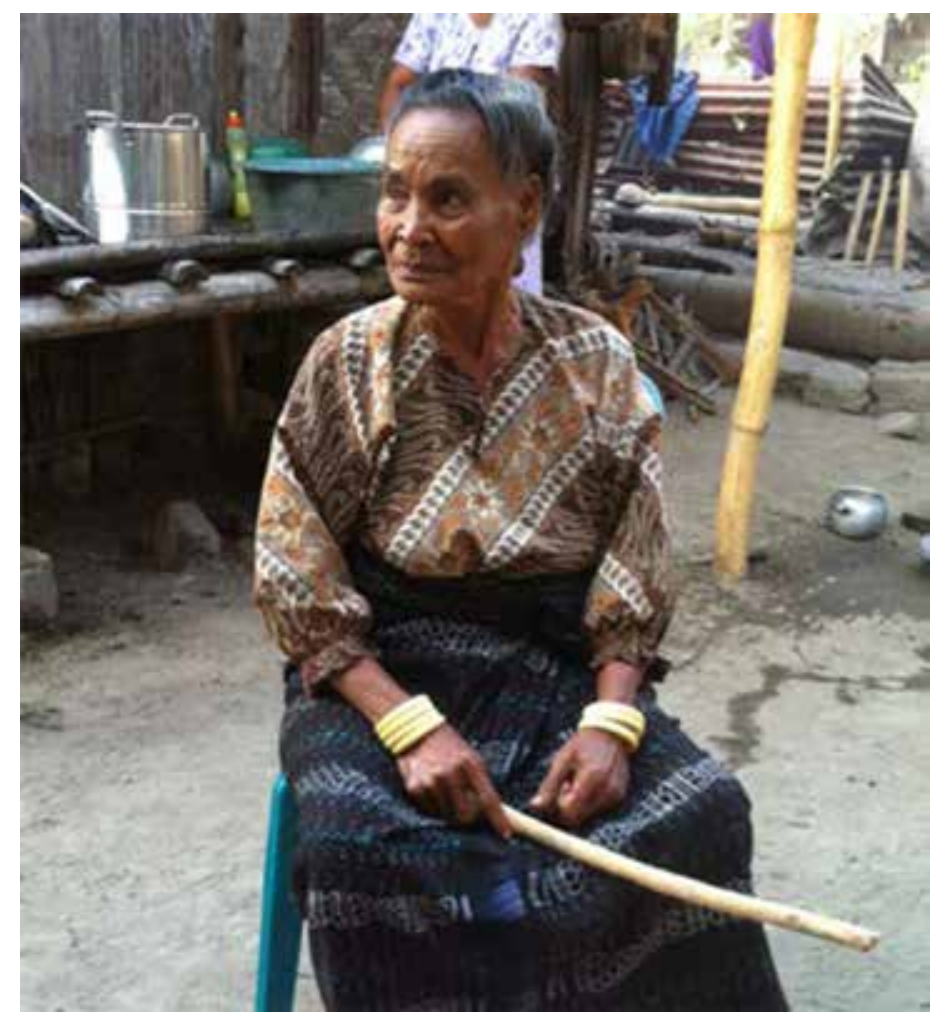

Picture 2. Magdalena Lue, wife of late adat leader Lakimosa Paso (circa 1927-2007), telling fairy-tales in the front yard, Lei, Keli (photograph by the author, 2014).

Hilarius Ratu (b. 1984) recalled how the children, and a few adults too, in kampong Ndeo used to gather outside on moonlight nights around Wilhelmus Wera (b. 1943), and listen to his hilarious storytelling. ${ }^{19}$ Nowadays people prefer to watch TV as a group during the few hours in which electricity is available in the evenings; other people pray, some children do their schoolwork. Traditionally, adha, including folk-tales, would be transmitted from the elders to the younger generation in the evenings, by a fire or in the dark, cramped traditional house (nua pi'i) thatched with long grass. Our most senior storyteller, Lengu Nandene, was about twelve years old at the time of the volcanic eruption and devastating tsunami in 1928, which she recounts in SD1-031. Lengu explained (in SD1-049) that her parents, Nua and Methi,

18 The girls Intan and Dewi, then 11 and 12 years old, told fables (SD1-016 and SD1-020) when I visited kampong Lei one afternoon. We sat by a table in the open area near their grandmother Magdalena Lue's house, where the children often gathered to chat, play and tell funny stories. Lue told a fable and a funny fairy-story (SD1-055 and SD1-056), see Picture 2.

19 Wera is a gifted and enthusiastic storyteller, and a master chanter in the large ceremonies. The stories we recorded in his home, on an inside woga, in kampong Hoka, 2-12-2014 (SD1007 - SD1-009), are good fun and fantastic, of the fairy-story type, replete with events and unexpected turns. 
and her uncle, Ngaji Legane, told her the tales in the evenings while she was still a child or in her youth. The storytelling took place in the evenings, in small groups. ${ }^{20}$

We have not paid to record, but as a rule have taken betel pepper and areca nut (Ind. sirih pinang), tobacco or a small bottle of Flores arrack for the more senior narrators. Eventually my position of being an insider-outsider, a familiar face who had made progress in Sara $L u^{\prime} a$, was probably beneficial, but my assistant Pidhu Sophune (b. 1979) was just as successful after he had mastered the recording skills. Perhaps he attained intimacy faster with the sources with which he was acquainted.

Cibo susu means 'to narrate in an orderly fashion' and the conjoined verbs are used for any genre. Nai noa (Ind. mendongeng) is suitable to either the fairystory or the fable. The presentation is divided into common categories which are not clearly separated from each other, either here or indeed anywhere generally speaking. I can only discuss a limited amount of the material between what is representative and more unique. ${ }^{21}$ I use the term "narrative" for any spoken account. "Story" and "tale" are slightly narrower. Oral history is a subdiscipline of history. Here "oral history" refers to a narrative which conveys personal/communal knowledge of past events and real persons/ancestors. An "ancestor tale" is a narrative about remote mythological ancestors.

\section{ORAL HISTORY}

Sara $L u^{\prime} a$ does not have a precise word for history. When such a concept is required, the Palu'e often use the Indonesian term. Oral history is rarely told in depth. The lakimosa families, who bear a greater responsibility for remembering them, are an obvious source of data, but it is neither certain that they are willing to tell what they know nor that they know more than somebody else who, for whatever reason, is also in the know. It was only after two months into my first, and longest, fieldwork on Palu'e that I was able to record something meaningful. In SD1-091 Sebastianus Sosu (b. 1944) tells about an uncle who once served some time in jail because he had participated in the traditional border warfare between enemy domains. He also recounts how children were sold in colonial times (approximately 1910-1949) for two reasons: poverty and the Dutch-imposed taxes. The unusually long recording $(29 \mathrm{~min}$.) is about the lives of close ancestors and sheds light on the island's history and its plight in the late colonial period. This story is of a type which I found useful and encouraged others, often seniors, to tell. The following fieldtrip in July 2014, when I had a decent command of Sara $L u^{\prime} a$ and knew what to look for and how to go about it, and people were more willing to contribute, I recorded the

20 Lee Haring suggests "folkloric restatement" as an approach to texts from and about folklore, and that history "comes to life through folkloric restatement" (2013:3). Folkloric restatement is made easy by video recordings, and aided by living voices, audio recordings, supplemented by photography. Imagine a performer, an audience and a social setting as described in the metadata or even according to descriptions of past performances.

21 See the Oxford English Dictionary (2017) for the definitions of "legend", "fairy-story", "myth", and "fable". 
same Sosu. I wanted him to tell about the legendary Ware Cane (Big Ware, a nickname from the 1900s), from the same kampong Nara, who allegedly had supernatural powers and was able to "fly-and-hide" (létu) people. Sosu begins the narrative (SD1-092): "So, in the past, here on Palu'e, there were a lot of ghost-witches. [...] There was a man by the name Big Ware. He used to 'fly-and-hide' people; he flew-and-hid both the healthy and the ailing". ${ }^{22}$

Another Sosu from Nara, deceased, and from the house in which we were recording, now his son's, was once discovered at the top of a candlenut tree in Nara, hanging from a tiny branch. All the villagers witnessed his predicament but there was no way they could reach him and bring him down. The only European resident, a missionary priest, came to help, but all they could do was to make a bed of coconut fronds on the ground below to cushion him if he fell. Finally, after two days, Ware arrived and said, "Sosu po mai" (Sosu descend), and he climbed down without falling. Sosu remained in a terrible state for days, but, after rituals had been conducted, including gifts of valuable goods to Ware, his health returned.

The second event, even more dramatic and strange, occurred in the early 1970s when Sebastianus Sosu was village head of Desa Ladolaka, ${ }^{23}$ and therefore responsible for taking action. In her youth in the early 1970s, Lebi, a woman who still lives in kampong Mata Mere near Nara, was once the victim of a similar event. She had been ill before she disappeared one night. The villagers called out to her and shouted, "A ghost-which is fly-hiding her!" People assembled and searched far and wide for two days in vain. On the third night, villagers saw a light "like a fire" on a hill. Many people chased after it and shouted, "Bo, Lebi-oo, bring back our Lebi", as was the custom. When they arrived on the hill to capture her and tie her up, she disappeared and the light reappeared in a new place. Finally people saw a light above a coconut palm in yet another location. Lebi was found there, tied upside down with lianas in the crown of the palm tree. Many of her relatives were there and ten people worked together to bring her down. She was unconscious and stank. Her family members carried her back to the village. Rituals were performed and goods were offered to Ware Cane, laid on his ancestor stone. Lebi recovered and does not remember anything of her ordeal.

Sosu went on to explain that there was no one else like Ware Cane in Nara, and speculates that Ware's powers were inherited as genes, which would define him as more a witch than a sorcerer. Ware would make people suffer to force them to pay their dowry instalments. He did not kill people, only severely disturbed them. Létu is now a phenomenon of the past, and the theme of a fairy-story (below) which must have its roots in oral history and tradition. The stories in Nara about Ware Cane, told by his relatives, have not

22 The ghost-witch is a category (ata nutu cani. lit. wild person ghost) which is as vague as its ways. Ata nutu canine is similar to the Eastern Indonesian term suanggi, which Bubandt (2016: 519) broadly defines as a "cannibalistic spirit-figure".

${ }_{23}$ There are eight administrative villages (desa) which each consists of several kampongs. The desa do not strictly follow domain borders. There are about 40 kampongs. 
yet crystallized into legend. Many sources have confirmed that ghost-witches haunted Palu'e until the early 1970s, when their numbers sharply decreased because of the influence of religion and other factors. ${ }^{24}$

Toji Cawane, a grandmother from kampong Cawalo, tells at length about ata nutune in a recording (SD1-297). Toji says that the ghost-witches were often from the same village. As a child she had once fallen ill or had hurt the insides of her legs and her father could not cure her. Toji saw the ghost-witch (Wongga), who came to pull at and throw something at her legs, once. Then Pisa Siko, a man with supernatural powers (ata pisa), ${ }_{1}^{25}$ and able to see ata nutune, was called upon. He asked if the family had any outstanding debts or were involved in any quarrels. Siko mentioned Wongga's name, and Toji's father said he did owe the man a small debt. Wongga was summoned and he admitted that it was he who had disturbed Toji. Toji's family gave Wongga's family beans and tubers. Pisa Siko teje (raise the palms of one's hands up) and received black powder medicine from God knows where in them, which he rubbed on Toji's legs, and she recovered. Toji said that most ghost-witches had disappeared after the natural disaster in 1973 which had caused such an enormous ravage of trees and bamboo, thereby destroying the places in which they used to hide and scare people.

A significant feature of the memorate is, according to Honko, that "it reveals those situations when belief in the supernatural became actualised" (1964: 14). In contrast to the memorate, that in Sydow's conception was a personal experience which often told of a supernatural experience, Sosu's narrative, SD1-092 in particular, belongs to both collective memory and tradition because there were hundreds of witnesses and létu is a Sara Lu'a term. Honko (1964) argues that memorates are the primary sources for the investigation of empirical evidence of supernatural beings, stories which can develop into legends, and that we can discriminate these tales from migratory narrations with knowledge of the tradition. In searching for stories about life in the past, it is likely that we shall come across legends which can be anything between real histories and stories which have morphed fiction and history into legends, hero narratives which might or might not be factually correct.

Ware Pa'e is a legendary historical character of the Keli domain. As he was a lakimosa, priest-leader, of Keli, it was necessary to ask the lakimosa family, Ware's descendants, to narrate his life-story. Ware Pa'e was the greatgreat grandfather of lakimosa Paso (circa 1925-2007). The story about his life was told at length by Franky Kombine (middle-aged), of Kampong Lei, the dwelling-place of the Keli lakimosa family. Ware Pa'e lived from the midnineteenth century well into the twentieth. ${ }^{26}$

Franky is from the parallel lakimosa descent group of Keli, and he names six generations in a direct line above himself. His narrative (SD1-017) is not yet a fabulate, but he insisted that he conveyed what the elders had passed 
on about Ware Pa'e as faithfully and completely as he could. His account contains a wealth of information about tradition, power, ritual and warfare. Franky says that Ware Pa'e was a pisa molo (Ind. dukun sakti), ${ }^{27}$ an awesome natural-born healer-witch, a type of person who was sorely needed in the recurring ritual warfare. Pa'e is ritual speech and Ware was surnamed Pa'e because of his ability to Pa'e, before a war or in healing. Whatever he spoke in Pa'e was certain to happen. Franky tells of a Pa'e duel between Ware Pa'e and Lule, another awesome pisa, in which they tried to bring a dead hen back to life using Pa'e. Ware won. It was Ware Pa'e who moved the ritual centre (dhubu) of Keli to their kampong Lei, and decided to sacrifice only one buffalo instead of the eight which previously were sacrificed in honour of Pio Pikariwu, the (probably) mythological founder of Keli's previous ritual centre at Nunu somba, and his seven helpers. Now the buffalo is intended for Pio, who then "shares the food" with his helpers.

When the Woto domain fought a border war with the domain of Hetho (Edo) which did not seem to being going well, they requested Dutch aid, and Dutch troops intervened. But, because the soldiers could not differentiate between Woto and Hetho people, the intervention ended in disaster, especially for Woto. The victims were so many they could not be buried, so they had to be thrown into a ravine, thereafter called Hule Amo. ${ }^{28}$ Divination played a major role in these conflicts. Before setting off to war, the pisa molo would tira nibi (perform a dream divination) to foresee, or even create, events. After their defeat, Woto sent people to buy Ware's dreams (peta nibi) with gold. Hetho did the same. Ware chose the side of Hetho. The purport was that the awesome pisa Ngajo Hejone of Woto would be shot when fetching the juice from his lontar palm. Ware Pa'e's dream became reality when his sharp-shooter, Mboe Sokone, shot Ngajo Hejone, thereby settling the outcome of the conflict. As a result of subsequent dreams and negotiations, Ware Pa'e was granted land in Woja, southeastern Palu'e, which was then settled by Keli people, whose descendants still live there today.

This victory was the main reason Ware Pa'e became Laki ndora (Lakimosa 'species of vine tuber'). Laki ndora is metaphor for expanding territory, made explicit in the ritual couplet associated with him: ca tana (expand territory), laki ndora. ${ }^{29}$

Two other sources tell at length about the Woto-Hetho war. In the narrative of Woko Kulane (b. 1938, SD1-007), from kampong Kaju Keri, Keli, the events

27 Ata pisa and ata pisa molo are essentially the same. Molo, meaning 'true' or 'accurate', suggests that the person's abilities are above those of the average ata pisa.

28 Hule means 'larvae'.

29 Ware Pa'e is remembered in the oral history song Laki ndora (SD1-126), composed in the 1980s by the now retired teacher Clara Sinta. The song praises Ware Pae's magical powers and success. The composer is a member of the laki ndora family, which means that her sources and their content are the same as Franky's. Metaphors in the song consist of ritual couplets. Laki ndora was sung by Maria Methi and her mother, Yuliana (Puine), Mata Mere, 8-07-2014. Methi, like other children, had sung the song in primary school, and was able to recover the complete text with the help of her family. 
and characters are largely the same, but the Dutch intervention takes place after Woto had lost land to Hetho with the help of Ware Pa'e.

Woto wanted the Dutch to capture Ware Pa'e, who found out about these plans and prepared an ambush. But the Dutch force climbed the wrong hill making towards Hetho and reached Woto, where misunderstandings led to a bloodbath in which most of the victims were Woto people. There were also exchanges of fire between Ware's men and Dutch troops. Thoka and Ngaji fired and hit the soldier's helmets, and then the soldiers retaliated, shooting them dead. Ware Pa'e was persuaded by other Palu'e leaders, awed by the firepower of the Dutch, to surrender. The Dutch came to disarm Keli and the other domains. Ware felt humiliated because they had surrendered without giving battle. He thought enough recompense would be made if they became Christian and did not have to pay taxes. Finally Ware and a group of Keli men were to be shipped to Maumere to register and work as labourers but, because of his magic powers, Ware was able to remain on the island. Later, the Dutch sent some visiting pastors and introduced the head-tax system.

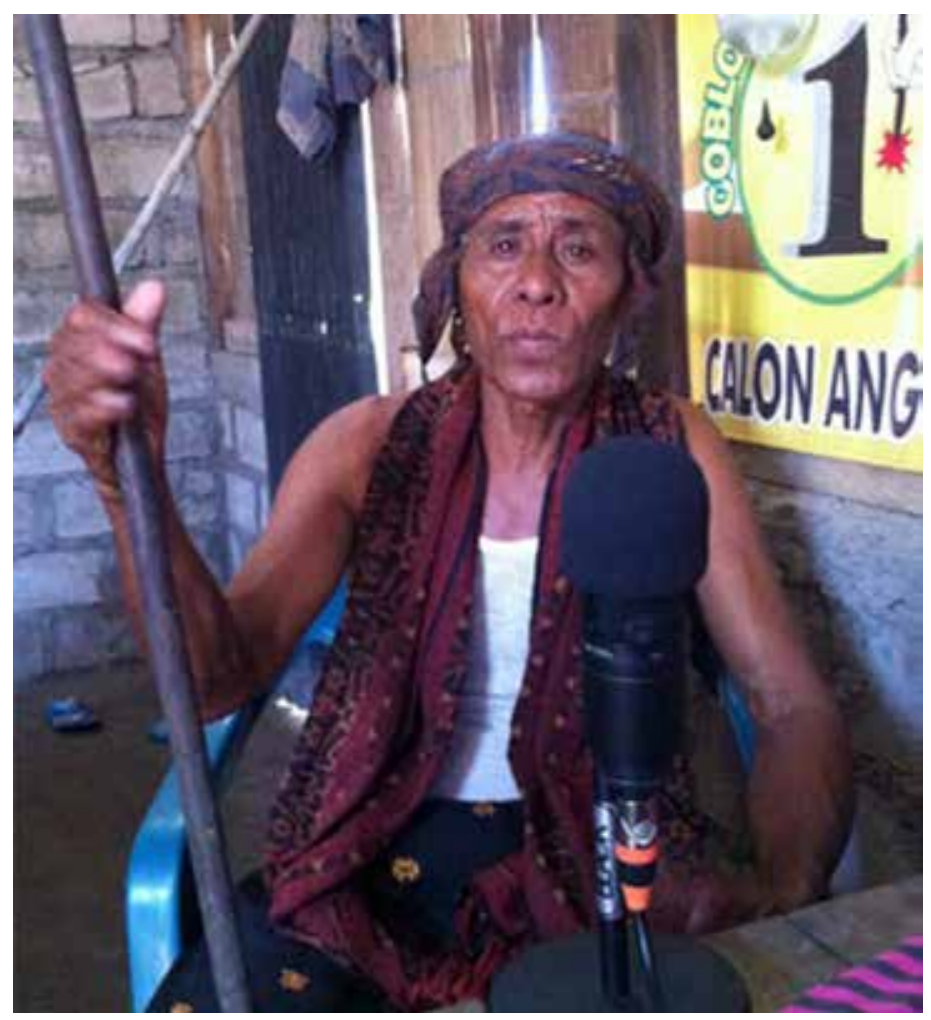

Picture 3. Bangu, lakimosa of Woto, wore traditional attire during the recording (photograph by the author, 2015).

In SD1-006, Bangu, grandfather and lakimosa of Woto (Picture 3), former enemy of Keli, gives a different view on events. He does not mention Ware Pa'e and Keli at all, and says it was Hetho which had requested Dutch aid: In the 
past Woto and Hetho had fought border wars. They shot at each other and both sides lost men. Hetho went to the Kapitan to ask that the Dutch intervene to restore order. ${ }^{30}$ Dutch troops arrived and Bangu's great-grandfather, Songgo, shot at the soldiers, splitting their helmets. Then the soldiers, guided by the Kapitan, climbed up to their village and created mayhem. The villagers ran towards Hule Amo to hide. When they were found, they had to surrender themselves, and their weapons and gold. The disarmament of both Woto and Hetho continued and order was restored.

Ware Pa'e is the only character so far mentioned in any resistance against the Dutch, with the exception of Songgo who, in Bangu's story, defended Woto against the Dutch attack. The Dutch intervention must have taken place in the first decade of the twentieth century when the Dutch pacified Flores and the eastern islands. Therefore I had expectations of finding traces of the conflict in the colonial archives (ANRI Timor n.d.). But all I found was a 1910 reference to the on-going, apparently slow-moving, disarmament which was heavily begrudged by the Palu'e and Ware Pa'e. The remaining muskets and rifles became heirlooms. After the Dutch disarmament bows and arrows became the main weapons in the border warfare of modern times.

No oral histories, in a strict sense, have told of events which must surely have occurred before the 1900s. This is how far memory, with the exception of genealogies, goes. Many myths and legends must actually stem from centuries past, but these are of little value to the study of history because they have no ties to known events and the outside world, which might shed light on when and in what context they appeared. The collection contains two lengthy oral histories about Mari Longa (SD1-058, SD1-107), the Lio resistance icon who was a contemporary of Ware Pa'e. His resistance began around 1900 and lasted until his last stand in 1908 and was widely reported by the Dutch (ANRI Timor n.d.). The sources are related to Mari Longa's descendants through the marriage of Mari's son, Wora, to a Palu'e woman. ${ }^{31}$ Some of the events they recount are found in the archives, others are not. Instances of the latter are the reasons behind the wars and, of course, Mari Longa's supernatural powers.

Other examples of oral history are the recordings about kidnappingheadhunting and construction sacrifice (SD1-118 - SD1-125), a frequent motif in Asian and European folklore. Danerek (2016) is a research article which makes explicit references to these testimonies of perpetrators/eyewitnesses, harnessed as oral history. ${ }^{32}$

30 Kapitan was the name for the local officer appointed by the Sikka Raja and/or the Dutch to collect taxes. The Kapitan system was introduced after pacification. Perhaps Bangu is confusing events in this war with a later conflict during the Japanese occupation which he speaks about in the same recording.

31 Their narratives are more complete than the narratives I was told by Mari Longa's direct descendants, whom I also visited. The latter have not been archived because of this, and because they are in Indonesian and about Lio.

32 The recordings focus on events and actions, and tell little about adat and folk belief. The latter were investigated by means of textual research and fieldwork. Several of these narratives, SD1-123 - SD1-125 in particular, had never been told at length and in detail before. The more sensitive of these have restricted access and all use narrator aliases. Access can be acquired 
Oral history; Personal narratives about tradition AND lOCAL WiSDOM

In SD1-102 Agus Wakene (middle-aged) from kampong Mata Mere tells of how a baby born extremely prematurely - "big as a rat" (Palu'e rats are small) - was cared for by his parents in a simple, but ingenious traditional way until it could be breastfed. For months the baby was kept in a small lontar box (dhudhu) on a bed of cotton. The parents fed it with the juice and milk of coconuts, administered on a piece of cotton put into the baby's mouth. The baby, Rugu, a relative of Agus, survived and could lead a normal life.

In SD1-054, Lunda, grandfather and healer from Mata Mere, tells about a baby in his family who was born the size of a gecko. Initially, the parents kept it in a dhudhu for three days. The two locally famous female healers or shaman-witches (ata pisa molo) of Keli, Methi Liru and Mbeo Pisane, who lived until the 1970s, both came to help. Although they thought the baby was dead, they quickly asked for many eggs to offer to the ancestors in a ritual (sisa somba) at a sacred place in the hills. Upon their return they ate a ritual meal and placed food at their rate (ancestor stone). Three days later the baby was healthy and looked like a human. After that Methi and Mbeo chewed betel pepper and areca nut with leaves from the hule mila plant, that are used ritually, and placed the mixture on the baby's navel, a healing method called ngiru. ${ }^{33}$ Methi also splashed water on the navel with a bunch of hule mila leaves. The child, Baga, grew healthy and lived well into adulthood, until he was killed by an arrow in a frontier skirmish.

In SD1-021, Joakina Pali tells about the customs in her village Mbako; the adat house for which she is responsible, including how it is constructed and her close ancestors. She tells in detail about the ka tara (lit. 'eat ill') ritual, to "eat people well" communally through the intervention of the ancestors, performed at the offering stone (rate) by the adat house. Ka tara is still performed all over Palu'e. Pali tells about the hulu pitu (sacred place and stone in each origin house) in her house, how burials are organized and about the adat of the domain (Teo), about her (grand)father who had a long dagger which they put on the rate at night, so that it could search and kill any enemy on its own. And many more such tales.

\section{LEGENDS}

I recorded Aloysius Sinde-Pima (middle-aged, see Picture 4) in Woja, 3 July 2014. Aloysius rarely narrates at length, but is known to be skilled in oral traditions, both in prose and in ritual language. While in high school he had a keen interest in Palu'e oral traditions. He often visited an elder, Ngange $\mathrm{Du}^{\prime} \mathrm{a}$, in kampong Nara, from where his ancestors migrated after Ware Pa'e was granted land in Woja. ${ }^{34}$ Ngange Du'a had a vast knowledge of Palu'e

upon request. About $98 \%$ of the recordings are open access.

33 Ngiru huru is a method of healing which uses betel pepper and areca nut slaked with lime, chewed with certain plants and applied to the patient's body to cure disease/symptoms (huru). It is TEK, Traditional Ecological Knowledge. Plant names and uses have been collected.

34 Aloysius also took notes when completing an assignment while in senior high school. 
oral literature, and often told stories to the young. Unfortunately he had passed away several years before my arrival in Nara. Luckily, Aloysius had memorized the tales very well.

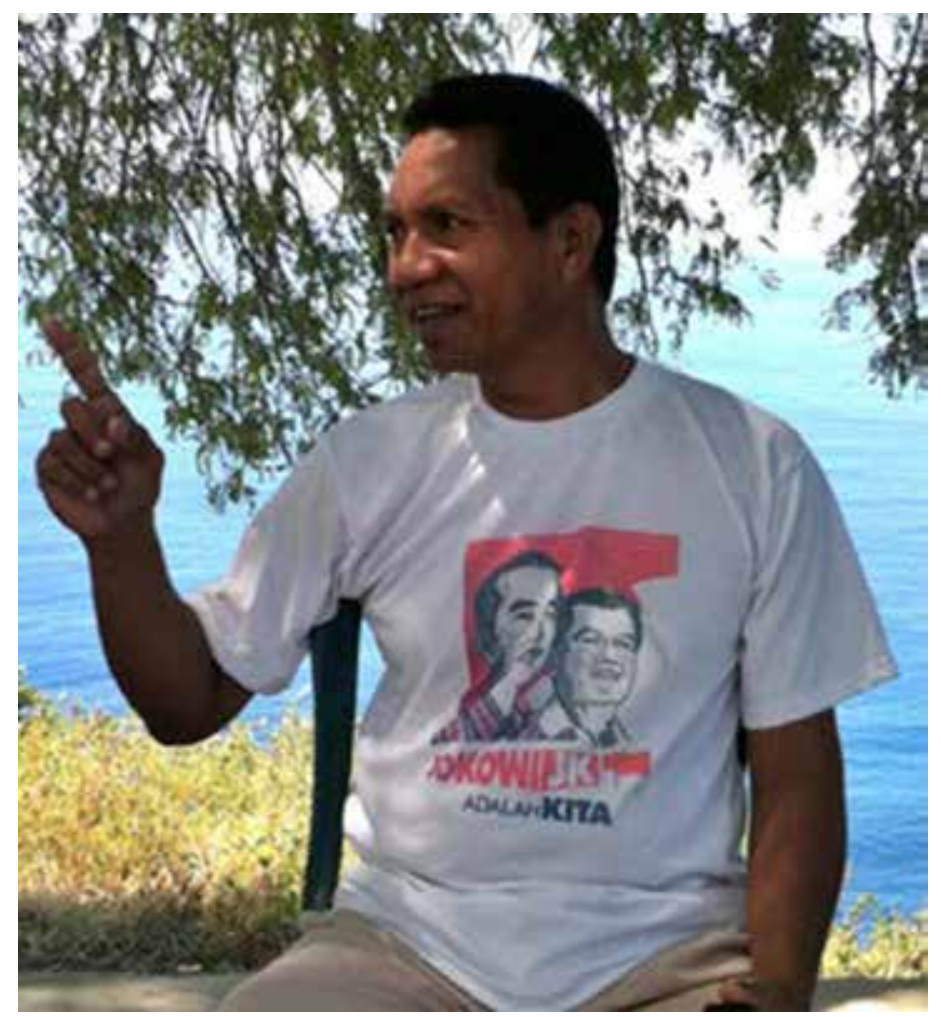

Picture 4. Aloysius Sinde-Pima, the village chief of Lidi, Woja (photograph by the author, 2014).

There are legends which are based on historical characters - ancestors. Because of reasons mentioned and their more magical content they tell more about folk belief and tradition, as well as about what is memorized and shaped into legend.

Ngange Kabe, a Nara ancestor who lived about ten generations ago, is just such a legend, but he is different to the legendary but obviously historical character Ware Pa'e. Aloysius Sinde-Pima's gave a long and magnificent rendering of the legend (SD1-001): ${ }^{35}$ Ngange Kabe was a pisa molo who was able to wave (kabe) at a boat and freeze it in its position with its crew at sea, with piratical intent. He did so after his relative from Nara, Ngasu, also a pisa molo, had returned from the village Sikka on Flores with valuable goods. They had seen, in "clear dreams" (nibi benga 'divination'), a woman who lived alone in a house on a hill with the goods. So Ngange and Ngasu travelled there one night and stole the goods. Ngasu got hold of the valuables first, so Ngange

35 The annotation document contains a free translation into Indonesian. 
considered them his and was too embarrassed to return empty-handed.

Back on Palu'e, standing at a certain place, he waved and froze a Bugis boat at sea. When this had been done, he paddled out and robbed those on board of their goods, including two named pieces of ivory which still exist in Nara. ${ }^{36}$ On the way back to Nara, Ngange told his followers that he would fall into a ravine and lie at death's door. He said that the only healer who would be able to help him was Dukun Ndasa from Maluriwu. He duly fell, was carried to Nara and was finally cured by Dukun Ndasa, who subsequently became his wife. Later, when Ngange was away for a long time clearing land, Dukun Ndasa became pregnant from a ray of light which visited her at night. Ngange Kabe's wife gave birth to a tiny, vulnerable baby, Cawa Lai, whose body resembled a small lizard but cried like a human. His dreams foretold Ngange that Cawa Lai would be great and influential, wiwi ca, lema lawa (lit. 'big lips', 'long tongue'), a manu molo (pisa molo), but the dream died with the baby when it was accidentally killed by a careless man.

Another legend is perhaps based on a historical character, or is it only a concocted legend? The character Pio pikariwu (Pio 'killer of many') presents an intriguing mystery. Everybody on Palu'e knows about Pio pikariwu and there are many short tales about him and his deeds in the collection. ${ }^{37}$ Pio is the subject of Palu'e's only prose epic, Pio pikariwu, told by Aloysius' in a one hour-long recording (SD1-128). Only a few people, perhaps only Aloysius, can tell the whole story of Pio at length and with an ordered structure of the events. ${ }^{38}$ It is a marvellous narrative, full of adventure, fighting, magic and warfare. The prevalence of magic and the deeper meaning of the characters' names suggest that Pio pikariwu is a myth, a work of fiction.

Pio appeared on Palu'e as a tiny-tiny baby, inside a bamboo tube which was washed up on the shore near Cawalo (village and domain), in a time when the Palu'e villages had already been established. The couple Soru and Pali from Cawalo heard his cries while they were searching for sea-snails. Soru kept cutting open the bamboo until he found a mini-baby, the size of a small lizard, in the eighth segment. The couple took the baby home, to poko lae bola, soko lae dhudhu, hamama no'o hina hama pu mori ('wrap in package, cover in box, like the ancestors'). ${ }^{39}$ After eight days in the box the little thing resembled a normal baby. The parents arranged a loge bundo, a name-giving

36 The colonial archives (ANRI Timor n.d.) mention Palu'e (also as Nusa Rajah) in the context of piracy. Other domains tell of characters who have the power to kabe. Bangu tells of another kabe, a Cua kabe (SD1-003). This makes sense within the worldview of inter-domain warfare and competition.

37 SD1-029, SD1-039, SD1-044, SD1-127 (song), and SD1-093, a legend about Siga of Ndeo who fought against Pio.

38 A senior Woja man sat with us and listened while recording. He was clearly able to follow the sequence of events, occasionally nodding or muttering a word or two. A forgotten part was recorded immediately afterwards, and I edited it into the first recording. I planned to record the legend once again, because we had better results with the recordings made later in the evening, but it has not happened yet.

39 Like in SD1-102 and SD1-054. Lengu Nandene's tale (SD1-044) also mentions cotton and $d h u d h u$, and compares the size of Pio to that of a baby rat. 
ceremony, at which they called the baby Pio. By the time that Pio was twelve he was stronger than all his friends and beat them in games and fights. He was so dominant he became a nuisance. Soru and Pali grew angry with him. Then, after seeing night-time bonfires, Pio discovered the different villages on Palu'e. He asked his siblings about the fires. As each village is mentioned, Pio replies: "I refuse to live there because [...]". The next part of the sentence describes and names the places in the village which became its adat name, in $P a^{\prime} e{ }^{40}$ This is one explanation of how the Palu'e villages received their long adat names. The only place in which Pio wanted to live was Dua nggéo, Nunu somba (lit. 'Bent lontar tree', 'Banyan worship'), which became the ritual centre of the Keli domain. He said that he would sit there and be paid respect/worshipped, and that from there he will "move himself around".

From then on, fighting dominates the narrative. As an adult, Pio, with seven helpers, conquered every village which did not pay him tribute ${ }^{41}$ Pio was a pisa molo and invulnerable. He hampered the enemy with thick fog, rains, strong winds, and even struck them with schools of fish from the sea. In the end, he and his helpers travelled to Flores where they were finally captured after a ritual chant dance $(\operatorname{tog} o)$. His capturers were unable to kill him, until Pio explained what they had to do: cook him in a huge cauldron on a fire made from banyan wood, his symbol and medicine. Pio disappeared as mysteriously as he had once appeared.

Both Keli and Cawalo, and their respective allies, consider Pio theirs. Cawalo discovered Pio and brought him up. But Pio chose to live in Keli. The lakimosa families of both domains use the name Pio.

The legend does not mention if Pio had any offspring, but Keli's lakimosa consider him as an ancestor. Is this a marvellous work of fiction or was there ever really an awesome Pio? Adding to the confusion is the fact that Pio has one or two alleged burial sites, and his heirloom sword still exists, exhibiting the damage incurred in a fight which is mentioned in the legend. ${ }^{42}$

\section{FAIRY-STORY, MYTH, ANCESTOR TALE}

Lengu Nandene (1916-2017, see Picture 5) deserves special mention, because I might have given up had she not been discovered by Maria Methi, one of my three assistants, in December 2014 during my fourth fieldtrip. She was hiding in plain sight as she had been living in the same village (Mata Mere) for almost a century. Lengu had been and still is a great storyteller. ${ }^{43}$ We recorded Lengu

40 Siu Dongge, kampong Dhure, Teo domain, told a shorter version of Pio pikariwu with most of the place names differing slightly from those mentioned by Aloysius. The place name sequence is found in SD1-108.

${ }_{41}$ This aspect of Pio, as a conqueror and killer, is dominant in SD1-044, entitled Dhubu da'u walu (Ritual centre of the eight). Eight refers to Pio and his seven helpers.

42 This sword, Keli sources informed me, was stolen from Lei, Keli, some years ago during inter-domain chant dancing. Allegedly, the thief was struck by lightning and died soon after. Much is at stake with Pio pikariwu.

43 Lengu is remembered as being skilled at togo, the ritual chant-dance, a talent she shared with her husband, Nande Lengune. On Palu'e, people add the name of one's husband or wife as 
on four different occasions in the house of Methi's parents, in the presence of a few family members and neighbours, with children peeking in from behind the curtains at the unglazed windows.

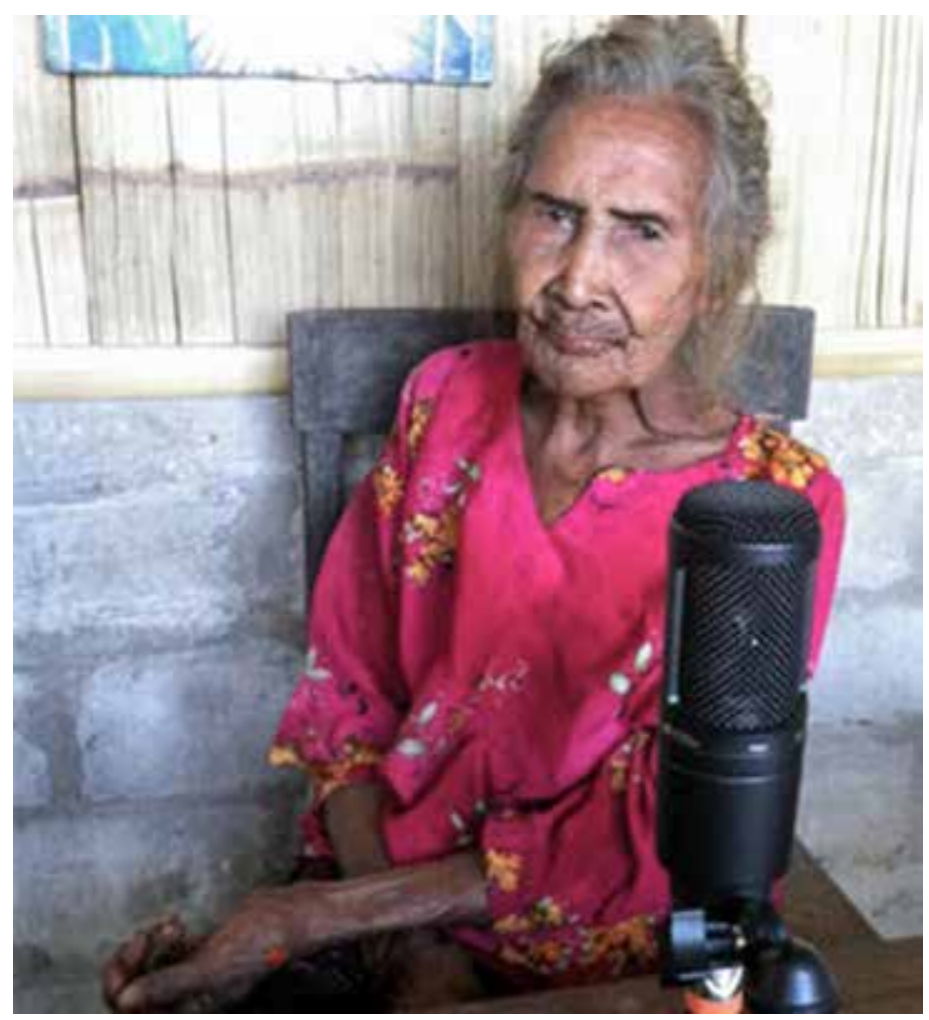

Picture 5. Lengu Nandene, at the second recording session. Mata Mere, Keli (photograph by the author, 2015).

She told eighteen folk-tales and several oral histories, including some interviewing, in pure Sara $\mathrm{Lu}^{\prime} a$, something which not all narrators are capable of. ${ }^{44}$ Lengu could even tell fairy-stories vividly, displaying empathy with the characters. She did not tell any of the more common and simpler funny fables. The two fables we recorded from her are longer, packed with events and characters galore, including humans (SD1-028 and SD1-033).

SD1-040, a fairy-story and a mystery with one plot, must be about the letu phenomenon: Roga's wife has been gone for seven days, and is nowhere to be seen. An elder tells Roga that, if she is not in the village and is not dead, then

identifier. The clitic -ne is a non-obligatory accentuation, similar to the Indonesian -nya. Before marriage it is the father's name, and only local names are added. She is "a great storyteller" because, although she passed away in May 2017, while the article was in copy-editing, her voice and her stories can still be listened to.

44 Among the difficulties was that Lengu was almost deaf. She had lost all her teeth and chewed areca nut and betel pepper - a requirement - so her voice is not optimally clear, but loud, firm and intelligible. In 2016, Lengu still worked on her family's plantation in the foothills of the mountains. 
she must be on the volcano. Roga searches until he reaches the volcano and speaks to a man there (perhaps a guardian of the volcano, one of the abodes of the ancestors). The man explains that his wife is there but says that Roga cannot meet her. The man tells the people inside the mountain to be quiet, after which they appear. Roga sees his wife among them. She sees him too, happy that he loves her so much, and tells Roga that she will return to the village after he has returned. When she finally does come back, her body and clothes are stinking of sulphur. What really happened is still a mystery but the last sentences give us a clue: Ama pu niu ia neréne aku ka'a nala ia. Bu'u a'e téna nuthune ngganggu, leka aku nala palu ia (God would have summoned her if I hadn't fetched her. Because the ghost-witches had taken possession of her, but I brought her back). ${ }^{45}$

Nangge Liru (Nangge Heavens, SD1-037) is a myth which tells of how the art of weaving came to the Earth (Palu'e): A woman from the heavens married a man from the Earth and lived in his village. However, there was no weaving and nobody who could teach the craft. So the woman decided to go to her parents in the heavens, above Nangge Liru. She travelled by magic, via an areca palm to which she made offerings, in response to which the tree stretched high up. Later her husband followed. Up there they were instructed by the parents to go to the eighth layer, where someone (God?) bestowed on them all the weaving implements and the expertise, which they brought back with them to the village on Earth.

SD1-036 is an amazingly adventurous tale about two young orphan brothers who were abducted by a giant man with huge ears, La'u Du'a. He asked them to pick lice from his ears, and when they did so he captured them inside his huge ears.

La'u Du'a then put the orphans inside a magic rock, which could be opened and closed by a mantra. He planned to cook them, like pigs, for the people who helped him work on his plantation the following day. The brothers managed to escape. They killed La'u Du'a by dropping him from a treetop, after they had helped him by pulling him up with a rope. After that the brothers went in search of a better life and found two sisters, and they became husbands and wives. The brothers knew about fire and how to cook, and they taught their wives how to use fire, so that they no longer had to warm the food in their armpits. They used fire to burn a cleared area for a field. When the village women saw the fire, koma lando (shining gold), for the first time, they tried to take as much as possible with them, and were burnt. Later they taught every house how to bojo haphi (make fire with bamboo and coconut husks), so that they could cook food.

Pidhu Sophune and Kanda Sera tell similar tales or versions of Lengu's tale about two young orphan brothers. In them, two-orphaned brother searched for a tree which could lead them to heaven, and the wua (areca) said that it could be, "tall, tall until it reached the heavens". In Pidhu's narrative (Ditu

\footnotetext{
45 Ngganggu is a Palu'e rendering of the Malay ganggu (disturb), which also denotes supernatural disturbances (gangguan).
} 
Wéa and Koli loi, SD1-086), the brothers escape from the giant Liru's ears while he sleeps and, after they have ascended the areca tree, they arrived at a place where there were only women, after which the plot is about the same. In Kanda's narrative (Doto no'o Walo, Kampong/ domain Ko'a, 12 June 2015), they managed to take along a drum and a gong (maba ko, adat instruments). ${ }^{46}$ But, before they had gone very far, the giant Pu Pu appeared, and the brothers killed him as they did in Lengu's version. Then they sounded the drum and gong and went up into the sky. The brothers married two sisters and cooked with fire. When the ignorant people in the heavens saw the fire they came and grabbed it, and burned their clothes and limbs.

The magic areca palm and the trip to heaven in the tales of Pidhu and Kanda also occur in Lengu's Nangge Liru (SD1-037). The motif of orphans and orphaned newcomers is prevalent in Flores and Eastern Indonesian origin narratives. On Palu'e, the adat name for the people/society under the lakimosa is wai walu (eight women), hana (child) halo (orphan in the Lio and Rongga languages of Flores) ${ }^{47}$ Wai walu can be interpreted as widows. Hence widows and orphans.

The couplet implies a dependency on the priestly class. ${ }^{48}$ Michael Vischer explains that the ordering is significant (2009: 257). Wai walu take first place and hana halo are those which come subsequently. In the tales just mentioned, the orphans are newcomers who are received by widows. I also understand this couplet to be a metaphor for the uprooted who left their lands in search of a new place to live.

There are also ancestor tales which tell about the first settlers on Palu'e. These tales do not have the same symbolically political significance as the origin narratives of the major ceremonial chants. However, Cawa Timbane told the tale Watu Pou (Rock boat, SD1-296) about first settlers and claimed to have followed the story strictly as his parents and grandparents had taught him.

Three ancestor pairs drifted on a boat from the west and arrived at Watu Pou, a rock by the Palu'e shore which was once their boat but is now a rock anchored to the island. The pairs have children and build a society. One of the sons, Langga, receives a divination in a dream which demands he has to sacrifice his child. As he is about to thrust a knife into his son who is unaware of what is happening, he hears a voice which says that from now on he must sacrifice a buffalo instead (like Abraham in the Bible and the Koran) and a buffalo appears. This how the buffalo sacrifice tradition began. Later the people moved from the hills of Awa (where buffalo sacrifice allegedly originated), to Ko'a, built a new ritual centre and continued to sacrifice buffalo.

46 In Pidhu's tale the women in Heaven greet the newcomers with maba weko (traditional drums and flutes).

47 Wayan Arka (2011: 3) glosses ana halo as a fatherless or motherless child.

48 James Fox (2014) analyses Rotinese ritual origin chants in which the motif of widows and orphans is prevalent. 


\section{FABLES}

The fable is a universal and easily recognized genre. Fables, featuring animal characters with their special traits, augmented by human traits, often describe bad manners and deceit. They are moral and didactic in the sense that the greedy or evil character always gets its just dessert. They are funny and the adult sometimes laugh as much as the children, as can be heard in some recordings. We have recorded over two dozen fables. ${ }^{49}$

The fable is a highly migratory genre, and it is to be expected that folktales have migrated through the Flores dialect chain and also through Malay/ Indonesian. Similar fables exist in Flores. ${ }^{50}$ One way to separate local fables, and other tales, from imports is to examine the behaviour of the characters. This will show whether they act and speak as people do in the local culture. Another factor which can be used is fauna. The first fable I recorded was $R^{\prime} a$ no'o Méo (The Monkey and the Cat, SD1-080), told by Paula Paji, an elderly lady from kampong Hoka, Ndeo. This monkey and cat tale might have originated from the nearby Lio. It explains one surprising fact about Palu'e fauna: there are no monkeys but there are cats.

Monkey and Cat are gathering molluscs (kima) in the sea near the shore. Cat finds molluscs but Monkey does not, so Monkey asks Cat why. Cat replies that he/they lower their lase (a Lio word for penis) as bait. Monkey tries Cat's trick in an attempt to catch a large mollusc, a type with an "open mouth", and his lase gets squeezed by the mollusc's shell when it closes its mouth (a climax which usually comes at the end of the tale). Monkey is hurt and cries for help, but Cat disappears. A Bugis boat passes by and the crew frees Monkey's lase from the mollusc, but they take him with them. Monkey fools the Bugis and escapes as they fire their rifles at him. He finds Cat and takes his revenge, assaulting all of his family and driving them off the Lio land to Palu'e, there to remain.

In Palu'e society, sharing is obligatory. Ata najane, the wife-giving relatives, often request (ci) things from ata wetane, their wife-receiving counterparts, who would be embarrassed about turning down the request. When speaking about general behaviour and common speech, the dichotomies: ka mbola (lit. 'eat good' or 'high good'), 'nice and generous' and ka ndoa (lit. 'eat bad'), 'stingy', are pervasive and important. In the fables told by Nggeno, daughter of Johannis Ware, from kampong Lei, who still entertains his grandchildren with stories, the characters exhibit $\mathrm{ka} \mathrm{mbola/ka} \mathrm{ndoa} \mathrm{behaviour} \mathrm{and} \mathrm{other} \mathrm{local}$ cultural traits. Coka mbele is to dance and show off one's arse as a form of humiliation, as in the past women would do behind the lines in inter-domain warfare to humiliate the enemy, or in a serious quarrel with another woman.

49 Excluding the many similar ones, with poor quality of sound (noise) read aloud by 4-6 graders in local storytelling classes, which I carried out with the aid of the teachers, who kept the notes for the local curriculum (muatan lokal). The children had to search for tales if they did not know any, and name the sources. There are many different fables with the same animals, hence the same title, but with different plots.

50 See, for instance, the tri-lingual book with Keo folk-tales (Baird and Tule 2003). 
In $R o^{\prime} a n o^{\prime} o$ De'u (Monkey and Rat, SD1-070), Monkey and Rat are on their home from a togo and are thirsty. After an argument about who is going to climb a coconut palm, Monkey climbs, picks, drinks and drops the empty coconuts which Rat is supposed to look after. Finally Rat has had enough, splits a coconut with a machete and hides beneath one of the halves. Monkey descends and hears Rat shriek ( $k i)$ and giggle, but cannot see Rat anywhere. Rat drives Monkey crazy, until he crushes his own testicles, to shriek too, with a stone, and dies. Then Rat appears and says, "You got what you deserve, trickster!" and does coka mbele.

In Dheke no'o Sololika (Swallow and Gecko. SD1-069), the pair go to cut bamboo to build their respective houses. Swallow is able to build his house, but Gecko never manages to finish his. Therefore Swallow perches on a small branch, dances and wiggles its butt. Because the gecko, unable to build a house, is content to remain inside a bamboo tube people say: "kau wa' a ngongo ama dheke, theke lae rose" (you are as stupid as a gecko, making noise inside a bamboo tube).

Other fables involve domesticated species: Hen, Buffalo, Pig, Goat, Sheep and Dog. Wild species: Crab, Crocodile (once probably existed in Flores), Caterpillar, Eagle, Raven, Turtle, and Civet Cat.

\section{OTHER LITERARY GENRES}

On Palu'e there are several non-prose genres which cannot be categorized as storytelling, but do narrate events or appear in prose narratives. Pa'e, the ritual language, is an art of words, ambiguous and allusive, building on semantic parallelism, a practice which is common in Austronesian societies, not least in Eastern Indonesia. ${ }^{51}$ Few people master it, but everybody knows many of the word pairs and couplets which are associated with each other. To invoke one means to invoke the other. So, the binary pair laki (man) and mosa (fat) which forms lakimosa can in a certain speech context, each by itself, refer to a lakimosa, and wai walu refers to the couplet wai walu, hana halo (society). $P a^{\prime} e$ follows formulae, but can also be improvised. It is the language of ritual ( $c i$ cawo, sisa somba) and bhulu wa'o, to bless and supplicate good health. ${ }^{52} \mathrm{~Pa}^{\prime} \mathrm{e}$ is also the language of place names which is so important in these societies, to name in pairs and couplets, and speak poetically about the environment, as Pio does in the legend. Many of the prose narratives contain lines of $P a^{\prime} e$ and, inevitably, idiomatic paired words.

Lee Haring's description of the Madagascar Merina poetic discourse, hainteny (Haring 2013: 24), which was influenced by Malayo-Polynesians, also describes $P a^{\prime}$ ' well. Hainteny translates as 'the art of the word' and "is a sort of verbal table tennis or duel". Its homonym ainteny means 'breath of the word or life of words'. Breathing life with words was literally what Ware Pa'e did in the $P a^{\prime} e$ duel with Lule (SD1-017), in which he brought a dead hen back to life.

51 See Fox (2014) about semantic parallelism and speaking in pairs.

52 The language of cursing, caba kore, is also like Pa'e. Ngiru huru healing often includes bhulu $w a^{\prime} o$. The collection includes over 100 ngiru huru narratives from about 50 different practitioners. 
Nowadays togo is only performed in the context of the major buffalo ceremonies, for five or more consecutive nights, and in new boat ceremonies (сеju pou/togo pou). There are some senior people, men and women, but not many, who still remember the oral literature which accompanies the major ceremonies. The togo chants in the buffalo ceremonies follow a structure and a rhythm but the lyrics are new for each event. Texts are metaphorical and ambiguous, like $\mathrm{Pa}^{\prime} e$, but are also from everyday speech. One party sings a riddle which usually ridicules (tio mbele) someone from another participating party who has to improvise an answer. This is the major form of Palu'e artistic expression.

In SD1-129, the senior master chanter of the Ko'a domain, Grandfather Woko Du'a, tells of how he composed a riddle for the togo performed for the Tomu domain's Pua Karapau in December $2014 .{ }^{53} \mathrm{He}$ also sings the main lines. A man from Cawalo had told them not to set off to fetch the buffalo, and that they would drown if they did. The ceremonies had been postponed until December, when conditions at sea are often ominous. But the weather turned out to be fine during the two-day journey and chanting on the boats to Lio and back. So Woko made a riddle about that.

At the end of the Pati Karapau rituals, on the third night after the sacrifice, Ro tolo is enacted from before midnight until the early morning. A group of singers, accompanied by gongs and drums, recite nati about the places and fauna which the mythological ancestors passed on their journey towards Palu'e. Ro tolo, led by master chanter Wilhelmus Wera, was recorded 7-8 February 2014 in Ndeo. The place names appear in couplets, as semantic parallelisms, and are important to the construction of mythologies which support certain descent groups. ${ }^{54}$

\section{CONCLUDING REMARKS}

This paper has showcased the contents of the collection and demonstrated why studies of the different types of folk-tales are essentially comparative and, by the same token, underline the need for a wide documentation. This and similar collections have a potential to cater to a wide audience, even nurses/midwives, as the items that tell about prematurely born babies have shown. These collections, which are often the result of lengthy and demanding fieldwork, are now available online. Researchers will be able to use and compare first-hand materials from different collections, like those of two related languages/ peoples, and link to them in their publications, which will increase accountability and veracity.

53 This event, its chants and rituals, was recorded at sea and on the beach. The togo was recorded in late January and early February 2014 when Ndeo performed the Pati karapau ritual. Video clips and audio were used, but the quality is not excellent because of the noise of the crowd, boat engines, gongs, and lamps. None of these recordings has yet been uploaded.

54 See Vischer (1992) for an analysis of the rituals and texts of the buffalo ceremonies and their socio-political importance. 
Palu'e oral literature still exists but, as everywhere else and other parts of the cultural lexicon, has been partly forgotten. It has been exchanged for watching TV and other activities. The oral personal narratives inform us about local history, beliefs and customs. Many narrators tell about family history, relatives who lived in the recent past and special events in their lives. This narrative type can be regarded as folklore and is a rich source for ethnography because it has been informed and shaped by tradition. It does not reveal the narrator's world view completely, but at least it provides a vivid window into his/her identity and world. Supernatural elements are common in both Palu'e folk-tales and personal narratives. Oral histories, legends and fairy-stories are illuminated by the more personal stories, and vice-versa, because the narrators and the personal stories are also shaped by tradition. Characters in Palu'e oral history and legends are awesome, possess supernatural powers (ata pisa molo), win battles and expand territory. The connection between language and power is strong, made most explicit in the oral history about Ware Pa'e. In fables, characters takes revenge on a stingy ( $k a$ ndoa) friend who does not share food and drink, a simple and universal didacticism. To some extent, all of these beliefs and values still inform and have a bearing on society today.

Our assessment of the language situation, which indicates both urgency and possibilities, drew our concerns towards the current contents of the Palu'e Audio Collection, intended to be a comprehensive resource for the language and culture of the Palu'e. The Sara Lu'a documentation project can, by virtue of its relatively technological-methodological simplicity as well as its requirement of few resources and low costs, serve as a model for the documentation of other communities in the region and beyond..$^{55}$

This does not mean that the project has been easy and never frustrating - the prime investigator is no Superman. It is better to have more than one investigator from the outset, each bringing his/hers skills. However, every project and its circumstances is different and impossible to predict in detail. The most important matter is to find local community members who are motivated to work towards the same goal, and who can go on to work with the documentation by themselves, should the prime investigator(s) not be able to continue.

\section{REFERENCES}

ARCHIVAL SOURCES

ANRI Timor. [n.d.]. K. 43. Arsip Nasional Republik Indonesia (ANRI, The National Archives of the Republic of Indonesia), Jakarta.

55 My assistant Hilarius Ratu noted that Sikka officials at the Tourism Office and intellectual members of other Flores communities saw our model of documentation as appropriate and one which should be urgently applied in their communities. Therefore the project has the potential to demonstrate to local people how they can collect and preserve their oral heritage before it is lost - if there is a will. 
Danerek, Stefan. 2016 - .Stefan Danerek Palu'e audio collection. Kaipuleohone, the digital language archive of the University of Hawai' $i$, Honolulu. [Https://scholarspace. manoa.hawaii.edu/handle/10125/38830, accessed 12-10-2017.]

\section{Publications}

Arka, I. Wayan (ed.). 2011. A Rongga-English Dictionary with English-Rongga Finderlist. Jakarta: Penerbit Universitas Atma Jaya.

Baird, Louise and Philipus Tule. 2003. Cerita rakyat Keo. Ende: Nusa Indah.

Bakhtin, Mikhail M. 1981. The dialogic imagination; Four essays. Translated by Caryl Emerson and Michael Holquist. Austin, TX: University of Texas Press.

Ben-Amos, D. 1971. "Toward a definition of folklore in context", The Journal of American Folklore (84) 331: 3-15. [Retrieved from: DOI: 10.2307/539729, accessed on 16-01-2017.]

Bubandt, Nils. 2016. "When in doubt. ..? A reply”, HAU: Journal of Ethnographic Theory 6(1): 519-530. [Response to Hau Symposium on Bubandt, Nils. 2014. The empty seashell: Witchcraft and doubt on an Indonesian island. Ithaca, NY: Cornell University Press.]

Danandjaja, James. 2010a. "Pendekatan folklor dalam penelitian bahan-bahan tradisi lisan", in: Pudentia MPSS (ed.), Metodologi kajian tradisi lisan, pp. 57-69. Jakarta: Asosiasi Tradisi Lisan (ATL).

Danandjaja, James. 2010b. "Folklor dan pembangunan Kalimantan Tengah; Merekonstruksi nilai budaya orang Dayak Ngaju dan Ot Danum melalui cerita rakyat mereka", in: Pudentia MPSS (ed.), Metodologi kajian tradisi lisan, pp. 71-84. Jakarta: Asosiasi Tradisi Lisan (ATL).

Danerek, Stefan. 2016. "Construction sacrifice in eastern Indonesia”, Indonesia and the Malay World (45)131: 88-107. [Online version retrieved from: http://dx.doi.org/10.1080 /13639811.2017.1247547, accessed on 22-092017. Print 2017.]

Dolby-Stahl, Sandra. 1989. Literary folkloristics and the personal narrative. Bloomington, IN: Indiana University Press.

Fox, J.J. 1998. “The linguistic context of Florenese culture”, Antropologi Indonesia 56: 1-11.

Fox, J.J. 2014. Explorations in semantic parallelism. Canberra: ANU Press.

Gippert, J., N.P. Himmelman, and U. Mosel (eds). 2006. Essentials of language documentation. Berlin: Mouton de Gruyter. [Trends in Linguistics: Studies and Monographs, 178.]

Haring, Lee. 2013. How to read a folktale; The "Ibonia" epic from Madagascar. Cambridge: Open Book Publishers. [Online version retrieved from: http:/ / books.openedition.org/obp/1356 accessed on 14-10-2017.]

Himmelmann, N.P. 1998. "Documentary and descriptive linguistics", Linguistics 36: 161-195.

Himmelmann, Nikolaus P. 2006. “Language documentation; What is it and 
what is it good for?" in: Jost Gippert, Nikolaus P. Himmelmann, and Ulrike Mosel (eds), Essentials of language documentation, pp. 1-30. Berlin: Mouton de Gruyter.

Honko, Lauri. 1964. "Memorates and the study of folk beliefs", Journal of the Folklore Institute 1 (1/2): 5-19. [Retrieved from: DOI: 10.2307/3814027, accessed on 11-01-2017.]

Klein, Barbro. 2006. "Telling, doing, experiencing; Folkloristic perspectives on narrative analysis; Introduction", in: Annikki Kaivola-Bregenhøj, Barbro Klein, and Ulf Palmenfelt (eds), Narrating, doing, experiencing; Nordic folkloristic perspectives, pp. 6-28. Helsinki: Finnish Literature Society. [Studia Fennica Folkloristica 16.]

Lewis, M. Paul, Gary F. Simons, and Charles D. Fennig (eds). 2017. Ethnologue; Languages of the World: Twentieth edition. Dallas, TX: SIL International. [Retrieved from: http:/ / www.ethnologue.com, accessed on 14-10-2017].

Maffi, Luisa. 2014. "Documenting and revitalizing oral traditions", in: Biocultural diversity toolkit, Vol. 4: 4-6. [Terralingua.org; Received in E-mail.] Oxford English Dictionary. 2017. Oxford: Oxford University Press. [Https:// en. oxforddictionaries.com, accessed on 17-03-2017.]

Pudentia MPSS (ed.). 2015. Tradisi lisan Nusantara dan warisan budaya. Jakarta: Asosiasi Tradisi Lisan and Direktorat Kepercayaan Terhadap Tuhan Yang Maha Esa dan Tradisi, Kementerian Pendidikan dan Kebudayaan. [Modul seri terbitan materi pelatihan pelestari tradisi tingkat dasar.]

Vischer, Michael. P. 1992. Children of the black patola stone; Origin structures in a domain on Palu'e island (Eastern Indonesia). Phd thesis, Australian National University. [Retrieved from: https:/ / digitalcollections.anu.edu. $\mathrm{au} /$ handle/1885/9986, accessed on 14-10- 2017.]

Vischer, Michael. 1993. "Palu'e", in: P. Hockings (ed.), Encyclopedia of World Cultures, Vol. V, East and Southeast Asia, pp. 204-209. New York: G.K. Hall and Company.

Vischer, Michael P. 2006. "Precedence among the domains of the Three Hearth Stones", in: James J. Fox and Clifford Sather (eds), Origins, ancestry, and alliance; Explorations in Austronesian ethnography, pp. 179-201. Canberra: ANU E Press. [Online version retrieved from: http://press.anu.edu. $\mathrm{au} ? \mathrm{p}=63701$, accessed on 14-10-2017.]

Von Sydow, Carl W. 1948. "On the spread of tradition", in: C. W. von Sydow, Selected papers in folklore, pp. 11-43. Copenhagen: Rosenkilde and Bagger.

TOOLS

ELAN. 2017. Version 5.0.0-beta. Max Planck Institute for Psycholinguistics, The Language Archive, Nijmegen, The Netherlands. [Computer software released on 18 April 2017, retrieved from: http://tla.mpi.nl/tools/tlatools/elan, accessed on 14-10-2017.]

Toolbox/Buseman, Alan and Buseman, Karen. SIL (Summer Institute for Linguistics) International. [Retrieved from: http://www-01.sil.org/ computing/toolbox/ accessed on 29-12-2016.] 


\section{APPENDIX}

RESEARCH ASSISTANTS

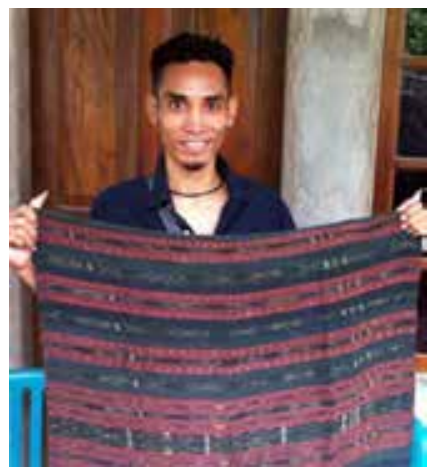

Hilarius Ratu, main assistant, displaying an old sarong (photograph by the author, 2016).

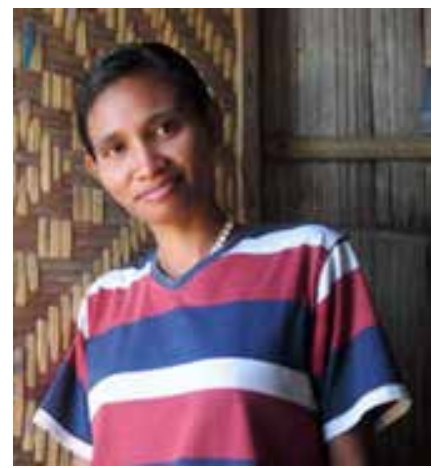

Maria Methi (Puine), assistant and storyteller (photograph by Mboe Puine, 2016).

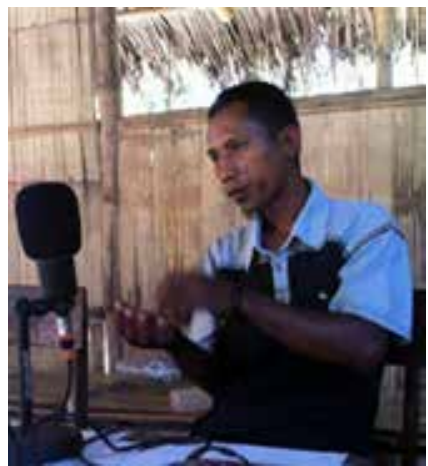

Pidhu Sopune, assistant, narrating during a workshop (photograph by the author, 2015). 